\title{
Prognostic Value of Albumin/Globulin Ratio in Patients with Upper Tract Urothelial Carcinoma Patients Treated with Radical Nephroureterectomy
}

\author{
HIROSHI FUKUSHIMA, MASAKI KOBAYASHI, KEIZO KAWANO and SHINJI MORIMOTO \\ Department of Urology, Tsuchiura Kyodo General Hospital, Tsuchiura, Japan
}

\begin{abstract}
Background/Aim: We investigated the prognostic role of the albumin/globulin ratio (AGR) in patients with upper tract urothelial carcinoma (UTUC) undergoing radical nephroureterectomy (RNU). Patients and Methods: AGR was calculated as follows: AGR=serum albumin/(serum total protein-serum albumin). Associations of preoperative AGR with disease-free (DFS) and overall (OS) survival were assessed in 105 patients with UTUC undergoing $R N U$. Results: Patients with preoperative $A G R<1.24$ and $\geq 1.24$ were classified into the low $(n=46,44 \%)$ and high $(n=59$, $56 \%)$ groups, respectively. The 5-year DFS and OS were $77 \%$ and $78 \%$, respectively. On multivariate analysis, high preoperative AGR was an independent predictor for both better DFS (hazard ratio $(H R)=0.34, p=0.038$ ) and $O S$ $(H R=0.24, p=0.006)$. The 5-year DFS and OS were significantly longer in the high-AGR group than in the lowAGR group (90\% vs. 60\%; $89 \%$ vs. $65 \%$, both $p<0.001$ ). Conclusion: The AGR has prognostic value in patients with UTUC undergoing $R N U$.
\end{abstract}

Upper urinary tract carcinoma (UTUC) is generally regarded as rare, but its incidence has increased to two cases per 100,000 person-years in the United States (1). Radical nephroureterectomy (RNU) is the gold standard treatment for localized UTUC. However, several large surgical series have shown poor prognosis after RNU; $20-30 \%$ of patients experience metastasis and eventually die from their disease $(2,3)$. In order to identify high-risk patients as candidates for adjunct therapies and clinical trials, and improve

Correspondence to: Hiroshi Fukushima, MD, Department of Urology, Tsuchiura Kyodo General Hospital, 4-1-1 Ootsuno, Tsuchiura, Ibaraki 300-0028, Japan. Tel: +81 298303711, Fax: +81 298463721, e-mail: fukuuro@tmd.ac.jp

Key Words: Albumin/globulin ratio, upper tract urothelial carcinoma, radical nephroureterectomy, survival. oncological outcomes, clinicians should have further knowledge of prognostic biomarkers. Several pathological parameters, including pT stage, tumor grade, and lymphovascular invasion (LVI), are generally used to predict prognosis after RNU (4, 5). Recently, serum C-reactive protein (CRP) was reported as a prognostic factor in patients with UTUC treated with RNU $(6,7)$. However, blood-based prognostic biomarkers have yet to be fully investigated in UTUC, and further research is mandatory in order to find novel prognostic biomarkers.

Albumin and globulin are two key serum proteins. Serum albumin reflects the nutritional status, and its lower value is related to poor prognosis in various diseases including cancer. Serum globulin reflects systemic inflammation, which can contribute to cancer progression. Thus, given the nature of these proteins, the albumin/globulin ratio (AGR) might be a strong prognostic factor for patients with cancer. Several recent studies have shown the prognostic significance of AGR in various malignancies (8-11). In the present study, we explored the prognostic role of AGR in patients with UTUC treated with RNU.

\section{Patients and Methods}

The Institutional Ethical Committee approved the present study protocol. We retrospectively reviewed 107 consecutive Japanese patients with UTUC who underwent RNU (extra-fascial resection of the kidney, entire length of the ureter, and adjacent segment of the bladder cuff) at our Institution between April 2003 and June 2016. Two patients with missing data on pathological examination were excluded and the remaining 105 patients were subjects for analysis. No patient received neoadjuvant therapy. Regional lymph nodes were dissected in patients with swollen nodes detected radiologically or intraoperatively. Adjuvant chemotherapy was administered at the discretion of physicians. Patients were generally followed-up every 3 months for the first year after RNU, every 6 months from the second to the fifth years, and annually thereafter with urinary cytology and cystoscopy. Computed tomography was generally conducted every 6 months for the first 5 years and annually thereafter. 
The following variables were reviewed: age at RNU, sex, tumor laterality, Eastern Cooperative Oncology Group performance status (ECOG PS), previous or concomitant bladder cancer, tumor location, tumor focality, tumor grade, $\mathrm{pT}$ and $\mathrm{pN}$ stages, LVI, concomitant carcinoma in situ, adjuvant chemotherapy, preoperative serum CRP, and preoperative and postoperative serum albumin and total protein.

Serum CRP was categorized according to a previous study (6). Serum globulin was calculated as follows: serum globulin=total serum protein - serum albumin. The AGR was calculated as follows: $A G R=$ serum albumin/(total serum protein - serum albumin). Postoperative serum albumin and total protein were measured within 1 month after RNU. Tumors were staged and graded in accordance with the 2002 TNM classification (12) and 1973 WHO grading system (13), respectively. LVI was defined as the existence of tumor cells within an endothelium-lined space with no underlying muscular walls.

The distribution of variables was compared between groups using the chi-squared test for categorical variables and Wilcoxon ranksum test for continuous variables. DFS was calculated from the date of RNU to the development of local recurrence or distant metastasis or last follow-up. OS was calculated from the date of RNU to death or the last follow-up. Survival curves were depicted by the KaplanMeier method and compared by the log-rank test. Variables associated with DFS and OS were explored using the Cox proportional hazards model. Variables with $p<0.10$ in the univariate analysis were included in the multivariate analysis. A reduced multivariate model was developed using the stepwise backward method, in which the variable with the highest $p$-value was eliminated from each iteration of the multivariate analysis. All statistical analyses were conducted using JMP 9.0.2 (SAS Institute Inc., Cary, NC, USA). A two-tailed value of $p<0.05$ was considered as significant.

\section{Results}

Table I shows the patient characteristics of the total cohort. The median (range) age at RNU was 74 (49-89) years, and $74(70 \%)$ patients were male. Fifty-three $(50 \%)$ patients had grade 3 tumors. pTa- 2 and pT3/4 tumors were observed in $71(68 \%)$ and $34(32 \%)$ patients, respectively. Of the 14 (13\%) patients who underwent regional lymph node dissection, two (2\%) had positive nodes. LVI was observed in $41(39 \%)$ patients. Adjuvant platinum-based chemotherapy was administered to $31(30 \%)$ patients. The median (range) preoperative albumin, globulin, and AGR were 4.1 (2.8-5.2) $\mathrm{g} / \mathrm{dl}, 3.2(2.4-5.5) \mathrm{g} / \mathrm{dl}$, and $1.26(0.62-1.88)$, respectively.

Next, we determined the cut-off point of AGR for its clinical use and further analyses. The optimal cut-off point of AGR was estimated as 1.24 by Youden's index of the receiver operating characteristics curve for overall mortality. Moreover, when the cut-off point was set as 1.24 , the corresponding hazard ratio (HR) was the lowest $(0.22, p=0.002)$ among the various cutoff points examined using the univariate Cox proportional hazards model. Thus, we determined 1.24 as the cut-off point for AGR. Patients with preoperative AGR $<1.24$ and $\geq 1.24$ were classified into the low (46 patients, $44 \%$ ) and high (59 patients, 56\%) AGR groups, respectively. Table I shows the relationships between AGR grouping and other variables. A significantly higher proportion of the low AGR group than the high AGR group had advanced age, multiple disease, high-grade tumors, high pT stage tumors, LVI, adjuvant chemotherapy, and high CRP level.

During follow-up (median=46 months; interquartile range $=22-83$ months), disease in 24 (23\%) patients progressed (5-year DFS $=77 \%$ ) and 20 (19\%) died (5-year $\mathrm{OS}=78 \%$ ). Variables significantly associated with DFS in the univariate analysis were ECOG PS, tumor focality, tumor grade, pT stage, LVI, adjuvant chemotherapy, preoperative CRP, and preoperative AGR (Table II). On multivariate analysis, preoperative AGR was an independent predictor for DFS $(\mathrm{HR}=0.34, p=0.038)$ along with ECOG PS $(p=0.013)$, tumor grade $(p=0.001)$, and pT stage $(p=0.029$, Table II). Age at RNU, ECOG PS, previous or concomitant bladder cancer, tumor focality, tumor grade, pT stage, LVI, preoperative CRP, and preoperative AGR were significantly associated with OS in the univariate analysis (Table III). Multivariate analysis revealed that preoperative AGR was an independent predictor for OS (HR=0.24, $p=0.006)$ along with ECOG PS $(p<0.001)$, and tumor grade $(p=0.004$, Table III). The 5-year DFS and OS were significantly longer in the high AGR group than in the low AGR group (90\% vs. 60\%, $p<0.001$, Figure $1 \mathrm{~A}$ and $89 \%$ vs. $65 \%, p<0.001$, Figure $1 \mathrm{~B}$, respectively).

Finally, postoperative AGR was evaluated in the group with low AGR. When postoperative AGR $\geq 1.24$ was defined as postoperative AGR recovery, eight (17\%) patients showed postoperative AGR recovery. Patients with postoperative AGR recovery had comparable 5-year DFS (75\%, $p=0.39$, Figure 2A) and OS (86\%, $p=0.94$, Figure $2 \mathrm{~B})$ to patients of the high AGR group. Patients with postoperative AGR recovery tended to have favorable DFS and OS compared with those without, but statistical significance was not reached ( $p=0.25$ and $p=0.13$, respectively).

\section{Discussion}

In the present study, we demonstrated the prognostic significance of preoperative AGR in patients with UTUC treated with RNU. Patients with high preoperative AGR had significantly longer DFS and OS than did those with low preoperative AGR. Multivariate analyses showed that preoperative AGR was an independent predictor for both DFS and OS. Therefore, preoperative AGR could be a prognostic biomarker in patients with UTUC, suggesting its usefulness in counseling patients on their personalized risk to determine therapeutic strategies including adjunctive therapies and clinical trials.

Interestingly, despite a low preoperative AGR, patients with postoperative AGR recovery had similar prognoses to those with high preoperative AGR. Although statistical 
Table I. Demographics and characteristics of patients with upper tract urothelial carcinoma undergoing radical nephroureterectomy (RNU).

\begin{tabular}{|c|c|c|c|c|}
\hline \multirow[t]{2}{*}{ Variable } & \multirow[b]{2}{*}{ Total } & \multicolumn{2}{|c|}{ AGR } & \multirow[b]{2}{*}{$p$-Value } \\
\hline & & Low & High & \\
\hline No. of patients $(\%)$ & $105(100)$ & $46(44)$ & $59(56)$ & \\
\hline Age at RNU (years), median (range) & $74(49-89)$ & $76(52-89)$ & $73(49-87)$ & 0.032 \\
\hline \multicolumn{5}{|l|}{ Gender, n $(\%)$} \\
\hline Male & $74(70)$ & $34(74)$ & $40(68)$ & \multirow[t]{2}{*}{0.50} \\
\hline Female & $31(30)$ & $12(26)$ & $19(32)$ & \\
\hline \multicolumn{5}{|l|}{ Tumor laterality, n (\%) } \\
\hline Right & $45(43)$ & $20(43)$ & $25(42)$ & \multirow[t]{2}{*}{0.91} \\
\hline Left & $60(57)$ & $26(57)$ & $34(58)$ & \\
\hline \multicolumn{5}{|l|}{ ECOG PS, n (\%) } \\
\hline $0-1$ & $101(96)$ & $44(96)$ & $57(97)$ & \multirow[t]{2}{*}{0.80} \\
\hline$\geq 2$ & $4(4)$ & $2(4)$ & $2(3)$ & \\
\hline \multicolumn{5}{|l|}{ Previous or concomitant bladder cancer, $\mathrm{n}(\%)$} \\
\hline No & $90(86)$ & $38(83)$ & $52(88)$ & \multirow[t]{2}{*}{0.42} \\
\hline Yes & $15(14)$ & $8(17)$ & $7(12)$ & \\
\hline \multicolumn{5}{|l|}{ Tumor location, n (\%) } \\
\hline Kidney & $41(39)$ & $15(33)$ & $26(44)$ & \multirow[t]{3}{*}{0.090} \\
\hline Ureter & $46(44)$ & $19(41)$ & $27(46)$ & \\
\hline Both & $18(17)$ & $12(26)$ & $6(10)$ & \\
\hline \multicolumn{5}{|l|}{ Tumor focality, n (\%) } \\
\hline Solitary & $80(76)$ & $29(63)$ & $51(86)$ & \multirow[t]{2}{*}{0.005} \\
\hline Multiple & $25(24)$ & $17(37)$ & $8(14)$ & \\
\hline \multicolumn{5}{|l|}{ Tumor grade, n (\%) } \\
\hline $\mathrm{G} 1 / 2$ & $52(50)$ & $15(33)$ & $37(63)$ & \multirow[t]{2}{*}{0.002} \\
\hline G3 & $53(50)$ & $31(67)$ & $22(37)$ & \\
\hline \multicolumn{5}{|l|}{ pT stage, n (\%) } \\
\hline pTa-2 & $71(68)$ & $21(46)$ & $50(85)$ & \multirow[t]{2}{*}{$<0.001$} \\
\hline $\mathrm{pT} 3 / 4$ & $34(32)$ & $25(54)$ & $9(15)$ & \\
\hline \multicolumn{5}{|l|}{ pN stage, n (\%) } \\
\hline $\mathrm{pNO}$ & $12(11)$ & $9(20)$ & $3(5)$ & \multirow[t]{3}{*}{0.066} \\
\hline $\mathrm{pNx}$ & $91(87)$ & $36(78)$ & $55(93)$ & \\
\hline $\mathrm{pN}+$ & $2(2)$ & $1(2)$ & $1(2)$ & \\
\hline \multicolumn{5}{|l|}{ LVI } \\
\hline No & $64(61)$ & $20(43)$ & $44(75)$ & \multirow[t]{2}{*}{0.001} \\
\hline Yes & $41(39)$ & $26(57)$ & $15(25)$ & \\
\hline Concomitant carcinoma in situ, $\mathrm{n}(\%)$ & & & & \\
\hline No & $69(66)$ & $31(67)$ & $38(64)$ & 0.75 \\
\hline Yes & $36(34)$ & $15(33)$ & $21(36)$ & \\
\hline Adjuvant chemotherapy, n (\%) & & & & \\
\hline No & $74(70)$ & $26(57)$ & $48(81)$ & 0.006 \\
\hline Yes & $31(30)$ & $20(43)$ & $11(19)$ & \\
\hline Preoperative CRP (mg/l), median (range) & $2.0(0.3-57.0)$ & $3.5(0.5-57.0)$ & $1.4(0.3-32.0)$ & $<0.001$ \\
\hline Preoperative albumin $(\mathrm{g} / \mathrm{dl})$, median (range) & $4.1(2.8-5.2)$ & $3.8(2.8-4.7)$ & $4.3(3.1-5.2)$ & $<0.001$ \\
\hline Preoperative globulin $(\mathrm{g} / \mathrm{dI})$, median (range) & $3.2(2.4-5.5)$ & $3.7(2.9-5.5)$ & $2.9(2.4-3.6)$ & $<0.001$ \\
\hline Preoperative AGR, median (range) & $1.26(0.62-1.88)$ & $1.08(0.62-1.24)$ & $1.43(1.24-1.88)$ & $<0.001$ \\
\hline
\end{tabular}

AGR: Albumin/globulin ratio; CRP: C-reactive protein; ECOG PS: Eastern Cooperative Oncology Group performance status; LVI: lymphovascular invasion; RNU: radical nephroureterectomy.

significance was not reached between patients with and without postoperative AGR recovery, patients with postoperative AGR recovery tended to have better survival than those without. Thus, perioperative changes in AGR could be used as a surrogate marker for better survival after
RNU in patients with UTUC with low preoperative AGR. Similarly, several previous studies showed that patients with postoperative normalization of CRP after RNU of UTUC had significantly longer survival than did those without $(6,7)$. Given the superior prognostic value of preoperative AGR to 
Table II. Univariate and multivariate analyses for predicting diseasefree survival of patients with upper tract urothelial carcinoma undergoing radical nephroureterectomy (RNU).

\begin{tabular}{|c|c|c|c|c|}
\hline \multirow[b]{2}{*}{ Variable } & \multirow{2}{*}{$\begin{array}{c}\text { Univariate } \\
p \text {-Value }\end{array}$} & \multicolumn{3}{|c|}{ Multivariate } \\
\hline & & HR & $95 \% \mathrm{CI}$ & $p$-Value \\
\hline Age at RNU (years) & 0.67 & & & \\
\hline \multicolumn{5}{|l|}{ Gender } \\
\hline $\begin{array}{l}\text { Male } \\
\text { Female }\end{array}$ & 0.50 & & & \\
\hline \multicolumn{5}{|l|}{ Tumor laterality } \\
\hline $\begin{array}{l}\text { Right } \\
\text { Left }\end{array}$ & 0.22 & & & \\
\hline \multicolumn{5}{|l|}{ ECOG PS } \\
\hline $0-1$ & 0.019 & ref. & $106-7532$ & 0013 \\
\hline \multicolumn{5}{|c|}{$\begin{array}{l}\text { Previous or concomitant } \\
\text { bladder cancer }\end{array}$} \\
\hline $\begin{array}{l}\text { No } \\
\text { Yes }\end{array}$ & 0.37 & & & \\
\hline \multicolumn{5}{|l|}{ Tumor location } \\
\hline $\begin{array}{l}\text { Kidney } \\
\text { Ureter/both }\end{array}$ & 0.51 & & & \\
\hline \multicolumn{5}{|l|}{ Tumor focality } \\
\hline $\begin{array}{l}\text { Solitary } \\
\text { Multiple }\end{array}$ & 0.036 & & & \\
\hline \multicolumn{5}{|l|}{ Tumor grade } \\
\hline $\mathrm{G} 1 / 2$ & $<0.001$ & ref. & & \\
\hline G3 & & 6.97 & $1.96-44.50$ & 0.001 \\
\hline \multicolumn{5}{|l|}{ pT stage } \\
\hline $\begin{array}{l}\text { pTa-2 } \\
\text { pT3/4 }\end{array}$ & $<0.001$ & $\begin{array}{l}\text { ref. } \\
2.69\end{array}$ & $1.10-7.12$ & 0.029 \\
\hline \multicolumn{5}{|l|}{ pN stage } \\
\hline $\begin{array}{l}\mathrm{pN} 0 / \mathrm{x} \\
\mathrm{pN}+\end{array}$ & 0.25 & & & \\
\hline \multicolumn{5}{|l|}{ LVI } \\
\hline $\begin{array}{l}\text { No } \\
\text { Yes }\end{array}$ & $<0.001$ & & & \\
\hline \multicolumn{5}{|c|}{$\begin{array}{l}\text { Concomitant carcinoma } \\
\text { in situ }\end{array}$} \\
\hline $\begin{array}{l}\text { No } \\
\text { Yes }\end{array}$ & 0.63 & & & \\
\hline \multicolumn{5}{|c|}{ Adjuvant chemotherapy } \\
\hline $\begin{array}{l}\text { No } \\
\text { Yes }\end{array}$ & 0.013 & & & \\
\hline \multicolumn{5}{|l|}{ Preoperative CRP } \\
\hline $\begin{array}{l}<5 \mathrm{mg} / 1 \\
\geq 5 \mathrm{mg} / 1\end{array}$ & 0.004 & & & \\
\hline \multicolumn{5}{|l|}{ Preoperative AGR } \\
\hline Low & $<0.001$ & ref. & & \\
\hline High & & 0.34 & $0.10-0.95$ & 0.038 \\
\hline
\end{tabular}

AGR: Albumin/globulin ratio; CI: confidence interval; CRP: C-reactive protein; ECOG PS: Eastern Cooperative Oncology Group performance status; HR: hazard ratio; LVI: lymphovascular invasion; ref: reference.

preoperative CRP in the present study, perioperative changes in AGR could be promising as a potential prognostic biomarker in patients with UTUC treated with RNU.
Table III. Univariate and multivariate analyses for predicting overall survival of patients with upper tract urothelial carcinoma undergoing radical nephroureterectomy ( $R N U)$.

\begin{tabular}{|c|c|c|c|c|}
\hline \multirow[b]{2}{*}{ Variable } & \multirow{2}{*}{$\begin{array}{c}\text { Univariate } \\
p \text {-Value }\end{array}$} & \multicolumn{3}{|c|}{ Multivariate } \\
\hline & & HR & $95 \% \mathrm{CI}$ & $p$-Value \\
\hline Age at RNU (years) & & 0.049 & & \\
\hline \multicolumn{5}{|l|}{ Gender } \\
\hline $\begin{array}{l}\text { Male } \\
\text { Female }\end{array}$ & 0.20 & & & \\
\hline \multicolumn{5}{|l|}{ Tumor laterality } \\
\hline $\begin{array}{l}\text { Right } \\
\text { Left }\end{array}$ & 0.13 & & & \\
\hline \multicolumn{5}{|l|}{ ECOG PS } \\
\hline $0-1$ & $<0.001$ & ref. & & \\
\hline$\geq 2$ & & 24.36 & $4.78-105.16$ & $<0.001$ \\
\hline \multicolumn{5}{|c|}{$\begin{array}{l}\text { Previous or concomitant } \\
\text { bladder cancer }\end{array}$} \\
\hline $\begin{array}{l}\text { No } \\
\text { Yes }\end{array}$ & 0.016 & & & \\
\hline \multicolumn{5}{|l|}{ Tumor location } \\
\hline $\begin{array}{l}\text { Kidney } \\
\text { Ureter/both }\end{array}$ & 0.057 & & & \\
\hline \multicolumn{5}{|l|}{ Tumor focality } \\
\hline $\begin{array}{l}\text { Solitary } \\
\text { Multiple }\end{array}$ & 0.003 & & & \\
\hline \multicolumn{5}{|l|}{ Tumor grade } \\
\hline $\mathrm{G} 1 / 2$ & $<0.001$ & ref. & & \\
\hline G3 & & 5.90 & $1.64-37.79$ & 0.004 \\
\hline \multicolumn{5}{|l|}{ pT stage } \\
\hline $\begin{array}{l}\text { pTa-2 } \\
\text { pT3/4 }\end{array}$ & 0.004 & & & \\
\hline \multicolumn{5}{|l|}{ pN stage } \\
\hline $\begin{array}{l}\mathrm{pN} 0 / \mathrm{x} \\
\mathrm{pN}+\end{array}$ & 0.26 & & & \\
\hline \multicolumn{5}{|l|}{ LVI } \\
\hline $\begin{array}{l}\text { No } \\
\text { Yes }\end{array}$ & 0.007 & & & \\
\hline \multicolumn{5}{|c|}{$\begin{array}{l}\text { Concomitant carcinoma } \\
\text { in situ }\end{array}$} \\
\hline $\begin{array}{l}\text { No } \\
\text { Yes }\end{array}$ & 0.24 & & & \\
\hline \multicolumn{5}{|c|}{ Adjuvant chemotherapy } \\
\hline $\begin{array}{l}\text { No } \\
\text { Yes }\end{array}$ & 0.42 & & & \\
\hline \multicolumn{5}{|l|}{ Preoperative CRP } \\
\hline $\begin{array}{l}<5 \mathrm{mg} / 1 \\
\geq 5 \mathrm{mg} / 1\end{array}$ & 0.003 & & & \\
\hline \multicolumn{5}{|l|}{ Preoperative AGR } \\
\hline Low & 0.002 & ref. & & \\
\hline High & & 0.24 & $0.07-0.67$ & 0.006 \\
\hline
\end{tabular}

AGR: Albumin/globulin ratio; CI: confidence interval; CRP: C-reactive protein; ECOG PS: Eastern Cooperative Oncology Group performance status; HR: hazard ratio; LVI: lymphovascular invasion; ref: reference.

Low preoperative AGR was significantly associated with advanced age, multiple disease, high-grade tumor, high pT stage tumor, LVI, adjuvant chemotherapy, and high CRP in 
A

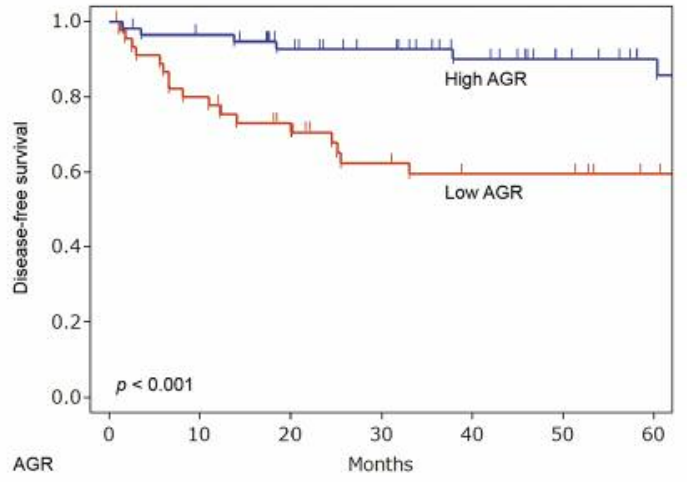

No. at risk

$\begin{array}{llllllll}\text { High } & 58 & 54 & 47 & 41 & 33 & 26 & 21 \\ \text { Low } & 46 & 36 & 29 & 23 & 20 & 20 & 16\end{array}$

B

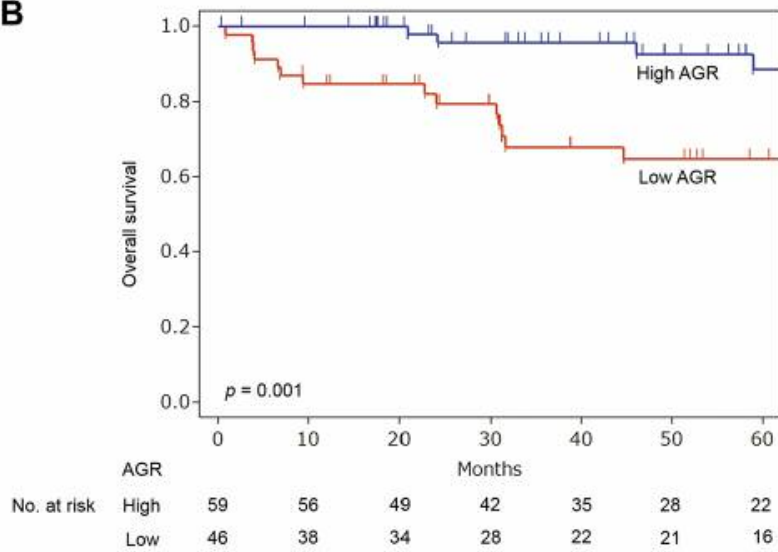

Figure 1. Disease-free (A) and overall $(B)$ survival curves of patients with upper tract urothelial carcinoma undergoing radical nephroureterectomy according to the preoperative albumin/globulin ratio $(A G R)$

the present study. This may imply that low preoperative AGR might reflect not only adverse pathological findings but also the presence of cancer cachexia. Cancer cachexia, characterized by fatigue, loss of appetite, weight loss, and frailty, involves host inflammatory responses to tumors (1417). Several previous studies reported the prognostic value of cachexia-associated factors, including CRP $(6,7)$, sarcopenia (18), and neutrophil/lymphocyte ratio (19), in patients with UTUC treated with RNU. Because serum albumin indicates the nutritional status, a lower albumin is frequently observed in patients with cancer cachexia. Serum globulin reflects systemic inflammation, which contributes to progression of cancer cachexia. Therefore, the AGR could be a strong indicator of cancer cachexia, which may explain its prognostic significance.

The present study has several limitations. Firstly, the present study was a retrospective single-institutional study with a relatively small patient cohort. Thus, our preliminary
A

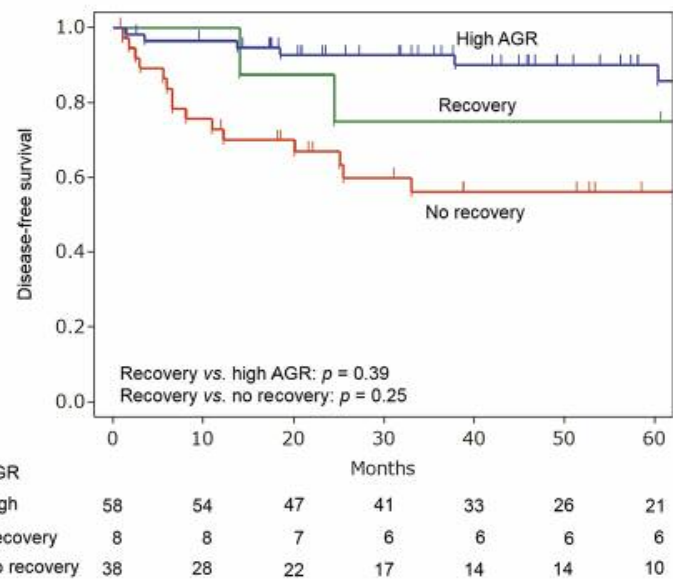

B

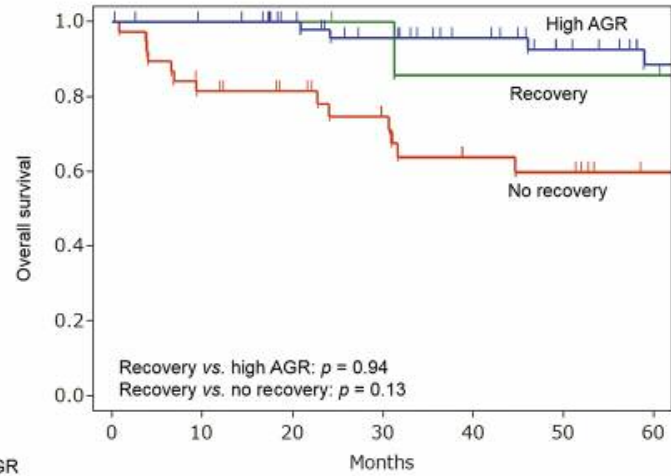

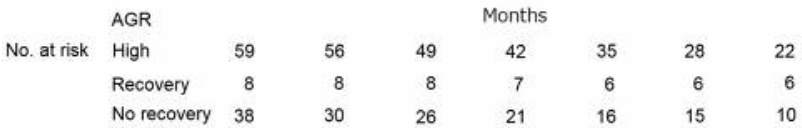

Figure 2. Disease-free (A) and overall (B) survival curves of patients with upper tract urothelial carcinoma undergoing radical nephroureterectomy according to the albumin/globulin ratio (AGR). Patients with a low preoperative AGR were classified into two groups according to the presence of postoperative AGR recovery.

results require validation in larger multicenter cohorts. Secondly, cachexia-associated factors, such as weight loss, body mass index, interleukin-6, fibrinogen, etc., were not extensively evaluated in the present study. Finally, we used 1.24 as the cut-off point of AGR in the present study, which is lower than the cut-off point used in previous studies (10, 20). In the previous study reported by Zhang et al. (20), the median AGR was 1.50, which is higher than that of the present study (1.26). Because high pT stage tumors and LVI were more frequently observed in the present study, the lower AGR value may have resulted from the higher proportion of cases of advanced disease in our cohort.

In conclusion, we demonstrated the prognostic significance of preoperative AGR in patients with UTUC treated with RNU. Patients with high preoperative AGR had 
significantly longer DFS and OS than those with low preoperative AGR. In addition, patients with postoperative AGR recovery showed comparable survival to those with high preoperative AGR. Although our results are preliminary and warrant validation in larger multicenter studies, they raise the possibility that the AGR can be useful as a prognostic biomarker in patients with UTUC treated with RNU.

\section{Conflicts of Interest}

None declared.

\section{References}

1 Raman JD, Messer J, Sielatycki JA and Hollenbeak CS: Incidence and survival of patients with carcinoma of the ureter and renal pelvis in the USA, 1973-2005. BJU Int 107: 10591064, 2011.

2 Cha EK, Shariat SF, Kormaksson M, Novara G, Chromecki TF, Scherr DS, Lotan Y, Raman JD, Kassouf W, Zigeuner R, Remzi M, Bensalah K, Weizer A, Kikuchi E, Bolenz C, Roscigno M, Koppie TM, Ng CK, Fritsche HM, Matsumoto K, Walton TJ, Ehdaie B, Tritschler S, Fajkovic H, Martinez-Salamanca JI, Pycha A, Langner C, Ficarra V, Patard JJ, Montorsi F, Wood CG, Karakiewicz PI and Margulis V: Predicting clinical outcomes after radical nephroureterectomy for upper tract urothelial carcinoma. Eur Urol 61: 818-825, 2012.

3 Roupret M, Hupertan V, Seisen T, Colin P, Xylinas E, Yates DR, Fajkovic H, Lotan Y, Raman JD, Zigeuner R, Remzi M, Bolenz C, Novara G, Kassouf W, Ouzzane A, Rozet F, Cussenot O, Martinez-Salamanca JI, Fritsche HM, Walton TJ, Wood CG, Bensalah K, Karakiewicz PI, Montorsi F, Margulis V and Shariat SF: Prediction of cancer specific survival after radical nephroureterectomy for upper tract urothelial carcinoma: development of an optimized postoperative nomogram using decision curve analysis. J Urol 189: 1662-1669, 2013.

4 Chromecki TF, Bensalah K, Remzi M, Verhoest G, Cha EK, Scherr DS, Novara G, Karakiewicz PI and Shariat SF: Prognostic factors for upper urinary tract urothelial carcinoma. Nat Rev Urol 8: 440-447, 2011.

5 Saito K, Kawakami S, Fujii Y, Sakura M, Masuda H and Kihara $\mathrm{K}$ : Lymphovascular invasion is independently associated with poor prognosis in patients with localized upper urinary tract urothelial carcinoma treated surgically. J Urol 178: 2291-2296; discussion 2296, 2007.

6 Saito K, Kawakami S, Ohtsuka Y, Fujii Y, Masuda H, Kumagai J, Kobayashi T, Kageyama Y and Kihara K: The impact of preoperative serum C-reactive protein on the prognosis of patients with upper urinary tract urothelial carcinoma treated surgically. BJU Int 100: 269-273, 2007.

7 Tanaka N, Kikuchi E, Shirotake S, Kanao K, Matsumoto K, Kobayashi H, Miyazaki Y, Ide H, Obata J, Hoshino K, Hayakawa N, Ito Y, Kosaka T, Kodaira K, Oyama M, Miyajima A, Momma T, Nakagawa K, Ueno M and Oya M: The predictive value of Creactive protein for prognosis in patients with upper tract urothelial carcinoma treated with radical nephroureterectomy: a multi-institutional study. Eur Urol 65: 227-234, 2014.
8 Deng Y, Pang Q, Miao RC, Chen W, Zhou YY, Bi JB, Liu SS, Zhang JY, Qu K and Liu C: Prognostic significance of pretreatment albumin/globulin ratio in patients with hepatocellular carcinoma. Onco Targets Ther 9: 5317-5328, 2016.

9 Fujikawa $\mathrm{H}$, Toiyama $\mathrm{Y}$, Inoue $\mathrm{Y}$, Imaoka H, Shimura T, Okigami M, Yasuda H, Hiro J, Yoshiyama S, Saigusa S, Kobayashi M, Ohi M, Araki T, Mohri Y and Kusunoki M: Prognostic impact of preoperative albumin-to-globulin ratio in patients with colon cancer undergoing surgery with curative intent. Anticancer Res 37: 1335-1342, 2017.

10 Liu J, Dai Y, Zhou F, Long Z, Li Y, Liu B, Xie D, Tang J, Tan J, Yao K, Zhang Y, Tang Y and He L: The prognostic role of preoperative serum albumin/globulin ratio in patients with bladder urothelial carcinoma undergoing radical cystectomy. Urol Oncol 34: 484.e481-484.e488, 2016.

11 Zhou T, He X, Fang W, Zhan J, Hong S, Qin T, Ma Y, Sheng J, Zhou N, Zhao Y, Huang Y and Zhang L: Pretreatment albumin/globulin ratio predicts the prognosis for small-cell lung cancer. Medicine 95: e3097, 2016.

12 Sobin LH and Wittekind C: TNM Classification of Malignant Tumors, Sixth Edition. New York, Wiley, 2002.

13 Mostofi FK, Sobin LH and Torloni H: International Histological Classification of Tumors: Histological Typing of Urinary Bladder Tumors. Geneva, World Health Organization, 1973.

14 Argiles JM, Lopez-Soriano FJ and Busquets S: Counteracting inflammation: a promising therapy in cachexia. Crit Rev Oncol 17: 253-262, 2012.

15 Fearon K, Strasser F, Anker SD, Bosaeus I, Bruera E, Fainsinger RL, Jatoi A, Loprinzi C, MacDonald N, Mantovani G, Davis M, Muscaritoli M, Ottery F, Radbruch L, Ravasco P, Walsh D, Wilcock A, Kaasa $\mathrm{S}$ and Baracos VE: Definition and classification of cancer cachexia: an international consensus. Lancet Oncol 12: 489-495, 2011.

16 Fearon KC, Voss AC and Hustead DS: Definition of cancer cachexia: effect of weight loss, reduced food intake and systemic inflammation on functional status and prognosis. Am J Clin Nutr 83: 1345-1350, 2006.

17 Muliawati Y, Haroen H and Rotty LW: Cancer anorexia cachexia syndrome. Acta Med Indones 44: 154-162, 2012.

18 Fukushima H, Nakanishi Y, Kataoka M, Tobisu K and Koga F: Prognostic significance of sarcopenia in upper tract urothelial carcinoma patients treated with radical nephroureterectomy. Cancer Med 5: 2213-2220, 2016.

19 Vartolomei MD, Mathieu R, Margulis V, Karam JA, Roupret M, Lucca I, Mbeutcha A, Seitz C, Karakiewicz PI, Fajkovic H, Wood CG, Weizer AZ, Raman JD, Rioux-Leclercq N, Haitel A, Bensalah K, Rink M, Briganti A, Xylinas E and Shariat SF: Promising role of preoperative neutrophil-to-lymphocyte ratio in patients treated with radical nephroureterectomy. World J Urol 35: 121-130, 2017.

20 Zhang B, Yu W, Zhou LQ, He ZS, Shen C, He Q, Li J, Liu LB, Wang C, Chen XY, Fan Y, Hu S, Zhang L, Han WK and Jin J: Prognostic significance of preoperative albumin-globulin ratio in patients with upper tract urothelial carcinoma. PLoS One 10: e0144961, 2015. 